\title{
СТУДІї О. КУРИЛО, М. СУЛИМИ, О. СИНЯВСЬКОГО І С. СМЕРЕЧИНСЬКОГО ЯК ПІДВАЛИНИ ВИВЧЕННЯ СТИЛІСТИЧНОЇ ГРАМАТИКИ УКРАЇНСЬКОЇ МОВИ
}

\author{
АНЖЕЛІКА ПОПОВИЧ \\ Кам'янець-Подільський національний університет імені Івана Огієнка, \\ Кам'янець-Подільський - Україна \\ likalika0409@gmail.com
}

\section{STUDIA O. KURYŁO, M. SUŁYMY, O. SYNIAWSKIEGO i S. SMERECZYNSKIEGO JAKO PODSTAWA BADAŃ GRAMATYKI STYLISTYCZNEJ JĘZYKA UKRAIŃSKIEGO}

ANŻELIKA POPOWYCZ

Narodowy Uniwersytet imienia Iwana Ohijenki w Kamieńcu Podolskim, Kamieniec Podolski - Ukraina

\begin{abstract}
STRESZCZENIE. Lata 20. i 30. XX wieku to okres powstania stylistyki języka ukraińskiego jako nauki i dyscypliny naukowej oraz jej kształtowania się wśród innych dziedzin językoznawstwa. W artykule poddano analizie prace Ołeny Kuryło, Mykoły Sułymy, Ołeksy Syniawskiego i Sergiusza Smereczynskiego z punktu widzenia odzwierciedlenia w nich zjawisk stylistycznych. Prace ukraińskich językoznawców stanowią fundament współczesnej morfologii i składni stylistycznej.
\end{abstract}

\section{STUDIES OF O. KURYLO, M. SULYMA, O. SYNIAVSKYI AND S. SMERECHYNSKYI AS FOUNDATION OF STUDYING STYLISTIC GRAMMAR OF UKRAINIAN LANGUAGE}

\author{
ANZHELIKA POPOVYCH \\ Kamianets-Podilsky Ivan Ohienko National University, \\ Kamianets-Podilsky - Ukraine
}

ABSTRACT. The 20-30-s of the $\mathrm{XX}^{\text {th }}$ century - is the foundation period for the Ukrainian language stylistics as a science and academic discipline and its formation on the verge of other branches of linguistics. In the article the works of Olena Kurylo, Mykola Sulyma, Oleksa Syniavskyi and Serhii Smerechynskyi have been analyzed from the point of view of the stylistic effects reflection. The works of Ukrainian linguists as the foundations of modern stylistic morphology and stylistic syntax have been considered.

-30-ті роки ХХ ст. прикметні становленням стилістики української
мови як науки й навчальної дисципліни та їі виформовуванням на
помежів'ї з іншими галузями мовознавства, зокрема історією укра-
їнської літературної мови, орфографією, лексикологією, граматикою, культу-
рою української мови, риторикою, основами теорії літератури тощо. С. Єрмо-
ленко зауважує, що стилістика постає, ,набуваючи ознак системи впорядкова-
них і взаємопов’язаних понять, проектуючись на галузь загального, теоретич-
ного мовознавства, а також сферу практичного оволодіння мовою”.

${ }^{1}$ С. Я. Срмоленко, Нариси з украӥнської словесності (стилістика та культура мови), Київ 1999, с. 260. 
„Українське мовознавство може пишатися багатьма справді блискучими постатями. Після блискучого троєзір'я 19 сторіччя - О. Потебні, К. Михальчука, П. Житецького другий гребінь піднесення знаменували двадцяті роки нашого сторіччя, коли працювали В. Ганцов, О. Курило, П. Бузук, Є. Тимченко, О. Синявський, М. Сулима, І. Зілинський, В. Сімович... Вагу цих мовознавців оцінив, між іншим, і совєтський режим: усі ці мовознавці, що були в сфері засягу режиму, були знищені, докладено всіх зусиль, щоб знищити їхні твори, замовчати відкрите ними", - беззаперечно стверджує Ю. Шевельов.

У період наступу на українізацію й репресивної політики ВКП (б) здійснювалися мовознавчі наукові дослідження, тривала робота з унормування української літературної мови, порушувалися питання про необхідність свого шляху та незалежності від впливу інших культур ${ }^{3}$ Ц зе знакові роки для української культури загалом і для мови зокрема.

Слушною вважаємо думку В. Ващенка про те, що „праці, далекі від стилістичного спрямування, суто граматичні, також не можуть обійти стилістичних явищ"

Напрацювання з проблем стилістики знаходимо в працях В. Сімовича Граматика української мови, О. Курило Уваги до сучасної української літературної мови та Паралельні форми в українській мові, їх значення для стилю, М. Сулими Украӥнська фраза. Коротенькі начерки, О. Синявського Норми украйнської літературної мови і Порадник украӥнської мови, С. Смеречинського Нариси з украӥнської синтакси (у зв'язку з фразеологією та стилістикою) та інших.

Мовознавчі розвідки, надруковані в 20-30-х роках XX ст., у радянських дослідженнях із лінгвістики згадуються побіжно, часто трактуються негативно. Лише пізніше С. Єрмоленко визнає: „Вивчення мовостилю як певної структурної цілісності, на відміну від опису стилістичних засобів української мови, розпочалося у 50-60-ті pp. 20 ст. До того часу стилістичні явища вивчалися у практичному плані як додаткова характеристика лексичних, фразеологічних, граматичних явищ, як засіб урізноманітнення, шліфування мови, вироблення загальнолітературних норм (праці мовознавців 20-30-х pp. 20 ст. О. Курило, I. Огієнка, М. Гладкого, Б. Ткаченка, О. Синявського, С. Смеречинського). На практиці об'єднувалися завдання стилістики і культури мови, або пуризму" .

3. Франко аналізує дослідження в галузі стилістики за означений період і переконує, що найбільш помітними є статті, рідше монографічні праці з культури мови 6 . 3-поміж студій, які не втратили наукової вартості, вона називає Паралельні форми в украйнській мові О. Курило.

Книга О. Курило Уваги до сучасної української літературної мови (1920р.) „попри непретензійність своєї назви, - неоціненний стилістичний порадник”: iii можна використовувати як основу курсу стилістики української мови. Ю. Шевельов пише, що вона стала „широким порадником в основних синтаксичноч. I, c. 5 .

${ }^{2}$ Ю. Шерех, Всеволод Ганцов. Олена Курило, за ред. Л. Білецького, Вінніпег 1954 р.,

${ }^{3}$ Л. Масенко, Мова і суспільство: Постколоніальний вимір, Київ 2004.

${ }^{4}$ В. С. В ащен но, Стилістичні явища в украйнській мові, відп. ред. М. Івчен ко, Харків 1958 , ч. 1 , с. 5.

5 С. Я. Єрмоленко, Стиль, [в:] Украӥнська мова: енциклопедія, редкол.: В. М. Русан ів ський, О. О. Тараненко (співгол.), М. П. Зяблюк та ін., Київ 2004, с. 652.

6 3. Т. Франко, Дослідження в галузі стилістики, [в:] Мовознавство на Україні за n’ятдесят років, від. ред. Й. А. Багму т, Київ 1967, с. 185.

${ }^{7}$ П. Таращук, Передмова, [в:] О. Кури л о, Уваги до сучасної украӥнської літературної мови, Київ 2004, с. 3-4. 
Студї О. Курило, М. Сулими, О. Синявського і С. Смеречинського як підвалини вивчення стилістичної граматики украӥнської мови

стилістичних питаннях української літературної мови"в і визначила наступний поступ на довгі роки.

Водночас були й негативні відгуки, у яких О. Курило визнавали „представником контрреволюційної програми української буржуазії в українському мовознавстві”, а іiї працю — „продовженням отої буржуазно-націоналістичної ошуканської програми під заялозеним, спаскудженим «народницьким» прапорцем, «згустком ідеології українського націоналізму»"9.

О. Курило охарактеризувала стилістичні особливості українського синтаксису, тому що не змогла розмежувати синтаксичні й стилістичні явища. Вона ставила за мету проаналізувати форми, непритаманні сучасній українській літературній мові, та запропонувати правильні, стилістично виважені. Зокрема вона переконує, що українській мові невластиві активні дієприкметники на -чий, -(в)щий, пасивні на -мий; деякі конструкції з дієслівними речівниками на -ння, пасивний предикат або пасивний атрибут з інструменталем дієвої особи ${ }^{10}$. До того ж, О. Курило тлумачить стилістичні особливості інфінітива, конструкції з особовими дієсловами, деякі іменні конструкції та безпідметові звороти, звороти з прикметниками, займенниками й числівниками, стилістичне навантаження категорії роду тощо.

Про вагомість праць О. Курило для розвитку стилістики української мови писали Л. Мацько ${ }^{11}$ і Н. Бойко ${ }^{12}$.

У 1928 р. професор науково-дослідної кафедри мовознавства Харківського інституту народної освіти М. Сулима надрукував розвідку Українська $\phi p a-$ за. Коротенькі начерки, у якій досліджував український стилістичний синтаксис у поєднанні з лексикою, семантикою та фразеологією на матеріалі українських художніх творів XIX - XX ст. О. Горбач називає цю студію “останньою об'ємистішою працею" вченого ${ }^{13}$. Зазначений автор адресував дослідження підліткам і дорослим для поглиблення й удосконалення знань 3 української мови, а також учителям української мови. У цій розвідці М. Сулима ${ }^{14}$ звертає увагу на:

- використання чоловічого й жіночого родів на позначення професій, посад тощо, порівн.: „Професійні й інші подібні до них назви в українській мові бувають здебільшого осібні для чоловіків і осібні для жінок. Українська мова взагалі уникає вживати в спільному роді тих слів, що означають посаду, професію, звання, рангу тощо, й надавати тим словам ознак граматичного (формального) чоловічого роду без огляду на стать... В українській фразі буває інакше: він - автор, вона - авторка; він - композитор, вона - композиторка; він - письменник, вона - письменниия; він - лікар, вона -лікарка; він - професор, вона - професорка й т. ін.";

- стилістичне навантаження спільного роду, його вживання в художньому та розмовному стилях;

${ }^{8}$ О. Кур ил о, Уваги до сучасної української літературної мови, Торонто 1960, вид. 5-те, с. 4.

${ }^{9}$ С. І І. В а с ил е в с ьк и й, Добити ворога, [в:], Мовознавство” 1934, № 1, с. 23-36.

${ }^{10} \mathrm{O}$. Курил о, зазнач. джер., с. 38.

${ }^{11}$ Л. Маць ко, Стилістичне унормування украйнської літературної мови у конщепиї̈ Олени Курило, [в:] Репресовані мовознавиі, зб. наук. праць, наук. ред. Н. Бо й ко, Ніжин 2010, с. 16-21.

${ }^{12}$ Н. Бо й ко, Олена Курило про стилістичне значення паралельних форм в українській мові, [в:] Репресовані мовознавиі..., с. 38-43.

${ }^{13} \mathrm{O}$. Го рб ач , ,Білі” й темні плями в історії мовознавства УРСР 1930-х рр., [в:] Електронний ресурс: http://r2u.org.ua/node/224 (11.01.2017).

${ }^{14}$ М. Сулима, Українська фраза. Коротенькі начерки, Харків 1928, [в:] Електронний реcypc: http://r2u.org.ua/node/188 (18.032017). 
- заміну однини множиною та навпаки, пошанну й авторську множину, заочну пошанну множину та їхнє стилістичне використання;

- стилістичні функції відмінкових форм іменників і категорій часу та способу дієслова і стилістичні особливості прикметників тощо.

Суголосними теперішньому часу є міркування про дієслівні форми на -но, -mo: „При дієслівних формах-присудках на -но й -mо у народній українській фразі не буває (це - закон!) орудного діяльника. Не можна по-народньому сказати, напр., так: „мною одержано листа”; треба ,я одержсав листа". За можливість орудного діяльника, звичайно, не можуть промовляти звороти старі книжні й оцерковнослов'янені фрази взагалі. Чужомовний орудний діяльника, хоч він і противний язиковим звичкам українського народу, дехто з наших письменників і взагалі інтелігентів заводить у свою мову. Все це - результат наслідування російської літературної мови, $\mathrm{i}$ - наслідування зовсім непотрібного. Орудний діяльника рідко буває навіть у такій собі інтелігентській балачці, i дозволяти його - це значить виявляти просто якийсь нерозбірливий лібералізм"15. М. Сулима стверджує, що українській мові непритаманне використання 3 присудками на -но й -то допоміжних форм було й буде: Було засіяно десятину з чвертю землі (Ів. Шевченко); В Польщі ії було заарештовано (Г. Брасюк); Ї̈й підсипано було чогось у питво (Ю. Будяк).

1931 р. побачив світ практичний підручник професора, завідувача відділу діалектології Інституту мовознавства ВУАН О. Синявського Норми української літературної мови ${ }^{16}$ (Харків-Київ, 1931). Учений почасти тлумачить стилістичні особливості відмінкових форм іменника, подає зауваги до використання прикметникових форм у художньому стилі та діловій мові, визначає їхні стилістичні функції, аналізує стилістичне використання дієслівних форм, характеризує різні “стилістичні ефекти” синтаксичних одиниць і т. ін.

Дещо пізніше Ю. Шевельов зауважує: „Тільки через двадцять років після появи «Норм» Синявського вийшов колективний «Курс сучасної української літературної мови» під редакцією Л. Булаховського, який де в чому переглянув підхід Синявського, а де в чому деталізував його, але ледве чи перевершив"17 та „особливо вирішально позначили своєю діяльність щодо розвитку української літературної мови" Тарас Шевченко, Борис Грінченко і Олекса Синявський ${ }^{18}$

Підвалини Норм украӥнської літературної мови О. Синявський заклав ще 1922 р. в Пораднику украӥнської мови ${ }^{19}$ (Харків-Берлін-Нью-Йорк). Тут автор звертає увагу на граматичні особливості сучасної української літературної мови й переконує в необхідності розвитку індивідуальних особливостей української мови попри безсумнівний взаємний вплив мов.

Тішить, що „усе істотне з усталеного Синявським збереглося до сьогодні. Усі совєтські зміни не спромоглися справді скасувати й знищити те, що зробив Синявський і його однодумці” ${ }^{20}$. За твердженням О. Горбача, „своєрідним від-

15 Tам само.

${ }^{16}$ О.С и н я в ськ и й, Норми украйнської літературної мови, Львів 1941.

17 Ю.В.Шевель ов, Нормалізація літературної мови, [в:] Електронний ресурс: http:// r2u.org.ua/data/other/Норми\%20української\%20літературної\%20мови,\%20Синявський\%20(1941). pdf (21.012017)

${ }_{18}$ Ю. Шевельов, Покоління двадиятих років в украӥнському мовознавстві, [в:] „Зап. Наук. тов-ва ім. Т. Шевченка”, Париж-Чікаго 1962, т. CLXXIII, с. 316-317.

19 О. Синявський, Порадник украӥнської мови, пристосований до буденного вжитку В. Сімов ичем, Харків-Берлін-Нью-Йорк 1922.

${ }^{20}$ Там само, с. 316. 
Студї О. Курило, М. Сулими, О. Синявського і С. Смеречинського як підвалини вивчення стилістичної граматики украӥнської мови

садком потебнянства - спершу в Варшаві, а після 1914 р. у Києві - став гурт дослідників стилістичної синтакси українщини з Євгеном Тимченком, Миколою Сулимою, Оленою Курило й, мабуть, Сергієм Смеречинським"21.

Нариси з украӥнської синтакси (у зв'язку з фразеологією та стилістикою) $)^{22}$ українського філолога С. Смеречинського призначені для фахівців, учителів-словесників, студентів-філологів. Тут автор пропагував уживання народнорозмовних конструкцій в усіх стилях, зокрема в публіцистичному й науковому. Об'єктом дослідження стала народна мова — автор базується на етнографічних матеріалах. С. Смеречинський досліджує такі стилістичні явища:

- безпідметові речення з формами на -но, -то як одну з найпоширеніших особливостей українського синтаксису;

- невластиве використання в українській народній мові при формах на -но, -то помічного дієслова, зокрема форм було, буде: було (буде видрукувано) $\rightarrow$ були видрукувані, видрукували, видрукувано;

- умови, за яких уживають безпідметові речення з формами на -но, -mo, а в яких - підметові;

-,„невластивість українській народній мові дієвої особи в орудному відмінку при формах на -но, -то та при пасивному присудку або пасивному атрибуті";

-,,коли та який орудний відмінок при пасивному присудку можливий”, особливості конструкцій з прийменником від та родовим відмінком дієвої особи; „безпідметові конструкції, що в них діє ніби щось «таємне», невідоме, якась сила" (чоловіка вбило, віз розбило, матросів потопило, попіл розмахало);

-,,конструкції з присудком на -ся (-mbcя, -лося), „особливості в згоді дієслова-присудка (коли він ув однині, а коли в множині) 3 підметом та зв'язані з ними стилістичні відтінки";

- особливості та стилістичну вагу спільного роду, „часові конструкції та їхні особливості в українській мові”; значеннєво-стилістичні функції окремих прийменників порівняно з російською та польською мовами; стилістичні відмінності відносних займенників і числівників; стилістичне використання футуральних форм з -му чи буду тощо.

С. Смеречинський віддзеркалює різні погляди українських дослідників на одне й те саме стилістичне явище, погоджується або заперечує їх. Він характеризує стилістичні норми побудови окремих синтаксичних конструкцій, правильне вживання відмінків, стилістичне навантаження категорії роду. Повсякчас дослідник звертає увагу на українську народну мову, порівнює стилістичні явища української мови 3 конструкціями, притаманними для російської, польської та інших мов.

Після появи Нарисів розпочалася їхня нищівна критика: „,автор сфальсифікував мовні факти, по націоналістичному висвітлив питання орудного присудкового; його висновки неправдиві, ворожі, шкідливі””2, „Праця С. Смеречинського є яскравий зразок боротьби націоналізму з творчим процесом розвитку української мови. Автор рішуче й категорично виступає проти пожовтневого мовного процесу"24. Мовознавця звинуватили в націоналістичному потрактуванні мовних фактів, його студію визнали найвиразнішою націоналістичною

${ }^{21}$ О. Горбач, Смеречинського „Нариси з украйнської синтакси”, [в:] С. Смеречинс ь к и й , Нариси з української синтакси (у зв'язку з фразеологією та стилістикою), Харків 1932, с. 9.

${ }^{22}$ С. Смереч и нс ьк ий, Нариси з української синтакси..., с. 6.

23 Українська мова у XX сторіччі: історія лінгвоциду. Документи і матеріали, за ред. Л. Масен ко, Київ 2005, с. 212.

${ }^{24}$ Там само, с. 218. 
розвідкою в українському мовознавстві, що фальсифікує явища української мови.

Негативні відгуки були й про праці О. Курило, А. Кримського, А. Вовка, Є. Тимченка, М. Гладкого, М. Сулими: „Це вони - агенти української буржуазії - усякий новий факт української мови таврували знаком «русизм» і таким чином уперто працювали над тим, щоб скувати розвиток української мови, щоб спрямувати його біг на капіталістичний шлях, щоб створити бар'єр між мовою українською і мовами братніх республік, зокрема мовою російською"25.

У 1957 р. І. Білодід намагався „осиковий кіл забити в могилу зліквідованих мовознавців-«двадцятників»” 26 . Він писав: „О. Курило, М. Сулима, С. Смеречинський і подібні пропонували «правила», — як в українській мові уникнути «чужої собі тропи, що нею йде російська мова», як «очистити» сучасну українську мову від «росіянізмів» і т. п. Націоналістичні мовознавці намагалися «вичистити» 3 української мови елементи в термінології, фразеології, синтаксичних конструкціях. Натомість рекомендувалося запроваджувати лінгвістичні раритети, застарілу і віджилу лексику, фразеологію, мовні елементи примітивнохуторянських смаків”27. Підтримував І. Білодіда й М. Жовтобрюх: „Найбільш сконденсовано архаїзаторські погляди на синтаксичну структуру української мови викладені в книзі С. Смеречинського «Нариси...» /1932/, тому вона не становить будь-якої наукової та практичної вартості...”28. Дозволимо собі не погодитися 3 цими твердженнями, адже в „20-30-ті роки написано славні сторінки історії українського мовознавства. Цей період вражає і грандіозністю глибоко продуманих і далекоглядних планів і задумів, і масштабами створеного невеликою кількістю талановитих, висококваліфікованих учених, і ще більше - трагізмом долі багатьох із них"29. Високо оцінював доробок О. Курило, О. Синявського, М. Гладкого, М. Сулими Б. Антоненко-Давидович, який називав праці українських учених мовознавців “вельми корисними"зо.

Незважаючи на те, що 1930-ті роки були оголошені добою “великого терору української мови”, а плідну працю мовознавців 20-х р. оголошено “шкідницькою й націоналістичною”, “спрямованою на відрив української мови від російської”, орієнтованою на народну мову й мову пам'яток ${ }^{31}$, стилістичні питання української мови активно потрактовувалися в загальномовознавчих розвідках В. Сімовича,О. Курило, М. Сулими, М. Гладкого, О. Синявського, С. Смеречинського. Відтак уважаємо, що в 20-30-ті рр. ХХ ст. стилістика української мови почала виформовуватися насамперед як наукова дисципліна, пов'язана 3 функціонуванням мовних засобів. Аналізовані праці О. Курило, М. Сулими, О. Синявського й С. Смеречинського — це підвалини сучасної стилістичної морфології й стилістичного синтаксису.

\footnotetext{
${ }^{25}$ C. I. В Василев ський, зазнач. джер., с. 30.

${ }^{26}$ О. Горбач, Смеречинського „Нариси з украӥнської синтакси”, [в:] С. Смеречинський, Нариси з украӥнської синтакси..., с. 14.

${ }^{27}$ І. К. Білодід, Вивчення історії украӥнської літературної мови в радянський час, [в:] Дослідження з мовознавства в УРСР за 40 рр., Київ 1957, с. 14-15.

${ }^{28}$ М. А. Жовтобрюх, Дослідження фонетики і граматики украӥнської мови, [в:] Мовознавство на Украӥні за п'ятдесят років, Київ 1967, с. 45.

${ }^{29}$ Т.Б.Лук і н о в а, 3 історї̈ Інституту мовознавства ім. О. О. Потебні, [в:] Інституту мовознавства ім. О. О. Потебні НАН України - 75, 1930-2005: матеріали до історії, редкол.:

В . Г. Скля ренко (відп. ред.) та ін., Київ 2005, с. 38.

${ }^{30}$ Б. Антонен ко-Дав идович, Як ми говоримо, Київ 1994, с. 5.

${ }^{31}$ Л. Масенко, зазнач. джер.
} 